\title{
Determination of Trace Elements in Silicon Powders by Inductively Coupled Plasma Quadrupole Mass Spectrometry With a Membrane Desolvation Sample Introduction System
}

\author{
Po-Kai Hsiao ${ }^{a}$, Shiuh-Jen Jiang, ${ }^{a, *}$, A.C. Sahayam ${ }^{b}$, and Ta Ching Hsiao ${ }^{c}$ \\ ${ }^{a}$ Department of Chemistry, National Sun Yat-sen University, Kaohsiung 80424, Taiwan \\ ${ }^{b}$ National Centre for Compositional Characterisation of Materials (CCCM), Hyderabad, India \\ c Metal Refining and Precision Milling Laboratory, Division of Metallic Materials Research, \\ MCL. ITRI, Hsinchu 31040, Taiwan
}

\begin{abstract}
An inductively coupled plasma quadrupole mass spectrometer, equipped with a desolvation sample introduction system, was successfully used for the accurate determination of $\mathrm{B}, \mathrm{Al}, \mathrm{P}, \mathrm{Ti}, \mathrm{Fe}$, and $\mathrm{Cu}$ in silicon powder samples. The effects of the operating conditions of the pneumatic nebulization membrane desolvation sample introduction system were optimized to achieve the best signal-to-background ratio for the elements studied. To avoid the vaporization loss of boron during sample dissolution, mannitol was added to the sample. The method alleviated the effects of polyatomic interferences at $\mathrm{m} / \mathrm{z} 27,31,47$, 48,56 , and 57 caused by ${ }^{28} \mathrm{Si}^{+}$ spread, ${ }^{14} \mathrm{~N}^{16} \mathrm{OH}^{+},{ }^{28} \mathrm{Si}^{19} \mathrm{~F}^{+}$, ${ }^{29} \mathrm{Si}^{18} \mathrm{~F}^{+},{ }^{28} \mathrm{Si}^{28} \mathrm{Si}^{+}$, and ${ }^{28} \mathrm{Si}^{29} \mathrm{Si}^{+}$ respectively. The detection limits
\end{abstract}

were better than $0.02,0.007,0.1$, $0.004,0.1$, and $0.002 \mathrm{ng} \mathrm{mL}^{-1}$ for $\mathrm{B}, \mathrm{Al}, \mathrm{P}, \mathrm{Ti}, \mathrm{Fe}$, and $\mathrm{Cu}$, respectively. The method was applied to the determination of $\mathrm{B}, \mathrm{Al}, \mathrm{P}$, $\mathrm{Ti}, \mathrm{Fe}$, and $\mathrm{Cu}$ in four solar-grade silicon powder samples. The accuracy of the procedure was verified by analyzing certified reference materials NIST SRM $1643 \mathrm{e}$ Trace Element in Water for $\mathrm{B}, \mathrm{Al}, \mathrm{Fe}, \mathrm{Cu}$ and NIST SRM 2711 Montana Soil for $\mathrm{Al}, \mathrm{P}, \mathrm{Ti}, \mathrm{Fe}, \mathrm{Cu}$. The concentrations of $\mathrm{B}, \mathrm{Al}, \mathrm{P}$, $\mathrm{Ti}, \mathrm{Fe}$, and $\mathrm{Cu}$ were determined by external calibration with $\mathrm{Rh}$ as the internal standard. Good agreement was obtained between the experimental results and the reference values. The precision between the sample replicates was better than $6 \%$ for all of the determinations

\section{INTRODUCTION}

Silicon is the most important material for use in the photovoltaic industry. More than $90 \%$ of the annual photovoltaic cell production is based on silicon, and the challenge is to reduce manufacturing costs. Metallurgical grade (MG) silicon (97-99\% purity) has been purified to the upgraded metallurgical grade (UMG) silicon, known as solar grade silicon, where impurity concentration has a crucial influ-

\footnotetext{
*Corresponding autbor.

E-mail: sjjiang@faculty.nsysu.edu.tw Fax: 886-7-5253908
}

ence on the energy efficiency. As a quality check, the silicon samples need to be analyzed for trace elements for which a sensitive and accurate method is required. Several methods such as total reflection X-ray fluorescence spectrometry (TXRF) (1-3), secondary ion mass spectrometry (SIMS) (4), laser-induced breakdown spectrometry (LIBS) $(5,6)$, and glow discharge mass spectrometry (GD-MS) (7) have been reported for trace element determination in silicon. However, the sensitivity of XRF is not sufficient for the determination of the lighter elements, such as $\mathrm{B}$ and $\mathrm{Al}$, studied in this work. Furthermore, it is difficult to determine low concentrations of analytes in silicon powder without the help of matrixmatched standards. The quantification of trace elements using SIMS is not straightforward and involves complicated calculations, and GDMS analysis requires the calculation of relative sensitivity factors (RSF).

Inductively coupled plasma mass spectrometry (ICP-MS) is a powerful technique for trace multielemental and isotopic analysis. This technique combines the characteristics of the ICP for atomization and ionization with the sensitivity of mass spectrometry. Alhough ICP-MS is a powerful technique for the measurement of trace elements, it is not always readily applicable for all elements in every possible sample. The determination of $\mathrm{B}, \mathrm{Al}, \mathrm{P}, \mathrm{Ti}, \mathrm{Fe}$, and $\mathrm{Cu}$ in silicon by quadrupole ICP-MS suffers from high background. With a large concentration of silicon in the sample, ICP-MS suffers from severe matrix suppression and a multitude of silicon-induced spectral interferences. As shown in Table I, the isotopes of $\mathrm{Al}, \mathrm{P}, \mathrm{Ti}, \mathrm{Fe}$, and $\mathrm{Cu}$ are interfered by various background ions. Furthermore, since boron is quite volatile, it might be lost during sample dissolution. Another issue with trace ppt level $\mathrm{B}$ analysis is background from the torch. Hence, the determination of $\mathrm{B}, \mathrm{Al}, \mathrm{P}, \mathrm{Ti}, \mathrm{Fe}$, and $\mathrm{Cu}$ in silicon powder by quadrupole ICP-MS is not an easy task. Mannitol $\left[\mathrm{C}_{6} \mathrm{H}_{8}(\mathrm{OH})_{6}\right]$ has been used to minimize memory 
effects (8) and reduce vaporization loss in sample pretreatment for boron determination (9). Chang et. al. (10) utilized an electrodialyzer equipped with an anion permeable membrane to separate matrix elements in the form of $\mathrm{SiO}_{4}^{-}$along with other anions such as $\mathrm{NO}_{3}{ }^{-}$and $\mathrm{F}^{-}$. For the anlaysis of silicon-based samples by ICP-MS, the matrixbased interferences are alleviated using octapole or dynamic reaction cell $^{\mathrm{TM}}(11,12)$. The introduction of a membrane desolvation sample introduction system is also an effective method for alleviating metal oxide ion spectral interferences in

The aim of the present work is to develop an easy and accurate method using pneumatic nebulization membrane desolvation quadrupole ICP-MS to determine trace amounts of $\mathrm{B}, \mathrm{Al}, \mathrm{P}, \mathrm{Ti}, \mathrm{Fe}$, and $\mathrm{Cu}$ in solar-grade silicon powder samples. The optimization of the pneumatic nebulization membrane desolvation ICP-MS technique and its analytical figures of merit, as well as its application to the determination of $\mathrm{B}, \mathrm{Al}, \mathrm{P}, \mathrm{Ti}, \mathrm{Fe}$, and $\mathrm{Cu}$ in silicon powder samples, are described. the ICP-MS analysis (13).

\section{EXPERIMENTAL}

\section{Instrumentation}

An ELAN ${ }^{\circledR} 6100$ DRC ${ }^{\text {TM }}$ II ICPMS instrument (PerkinElmer ${ }^{\circledR}$, Inc. Shelton, CT, USA) was used for the analyses. The samples were introduced by a membrane desolvation sample introduction system (Aridus-I, Cetac, Omaha, NB, USA). Solutions of $0.1 \%(\mathrm{~m} / \mathrm{v})$ dissolved silicon

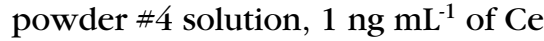
in $1 \%(\mathrm{v} / \mathrm{v}) \mathrm{HNO}_{3}$ and $1 \%(\mathrm{v} / \mathrm{v})$ $\mathrm{HNO}_{3}$ (to be treated as the blank) were introduced into the nebulization system successively. The aerosol generated was then transported to ICP-MS for the determination of the ion signals. The conditions of the pneumatic nebulization membrane desolvation sample introduction system were selected to give the best signals for the elements studied while minimizing the spectral interferences effectively. The operating conditions of the membrane desolvation ICP-MS system used in this work are summarized in Table II.

\section{Reagents}

Suprapur® $\mathrm{HNO}_{3}(70 \% \mathrm{~m} / \mathrm{m})$ and $\mathrm{HF}(35 \% \mathrm{~m} / \mathrm{m})$ were obtained from Merck (Darmstadt, Germany). Mannitol and $\mathrm{Si}, \mathrm{Al}, \mathrm{Cu}, \mathrm{Fe}, \mathrm{P}, \mathrm{Rh}$, and Ti ICP standard solutions were also from Merck. A boron standard solution was obtained from High

TABLE I

Isotopes of Interest and Most Abundant Polyatomic Interferences

\begin{tabular}{ccl}
\hline Isotope & Abundance (\%) & Interferences \\
\hline${ }^{27} \mathrm{Al}$ & 100 & ${ }^{28} \mathrm{Si}$ spread \\
${ }^{31} \mathrm{P}$ & 100 & ${ }^{30} \mathrm{SiH},{ }^{14} \mathrm{~N}^{16} \mathrm{OH},{ }^{15} \mathrm{~N}^{16} \mathrm{O}$ \\
${ }^{47} \mathrm{Ti}$ & 7.32 & ${ }^{28} \mathrm{Si}^{19} \mathrm{~F},{ }^{29} \mathrm{Si}^{18} \mathrm{O},{ }^{15} \mathrm{~N}^{16} \mathrm{O}^{16} \mathrm{O}$ \\
${ }^{48} \mathrm{Ti}$ & 73.98 & ${ }^{29} \mathrm{Si}^{19} \mathrm{~F},{ }^{14} \mathrm{~N}^{16} \mathrm{O}^{18} \mathrm{O}$ \\
${ }^{49} \mathrm{Ti}$ & 5.46 & ${ }^{30} \mathrm{Si}^{19} \mathrm{~F}$ \\
${ }^{54} \mathrm{Fe}$ & 5.82 & ${ }^{40} \mathrm{Ar}^{14} \mathrm{~N},{ }^{38} \mathrm{Ar}^{16} \mathrm{O}$ \\
${ }^{56} \mathrm{Fe}$ & 91.66 & ${ }^{40} \mathrm{Ar}^{16} \mathrm{O},{ }^{28} \mathrm{Si}^{28} \mathrm{Si}$ \\
${ }^{57} \mathrm{Fe}$ & 2.19 & ${ }^{40} \mathrm{Ar}^{17} \mathrm{O},{ }^{28} \mathrm{Si}^{29} \mathrm{Si}$ \\
${ }^{63} \mathrm{Cu}$ & 69.17 & ${ }^{47} \mathrm{Ti}^{16} \mathrm{O},{ }^{28} \mathrm{Si}^{35} \mathrm{Cl},{ }^{28} \mathrm{Si}^{17} \mathrm{O}^{18} \mathrm{O},{ }^{40} \mathrm{Ar}^{23} \mathrm{Na}$ \\
${ }^{65} \mathrm{Cu}$ & 30.83 & ${ }^{47} \mathrm{Ti}^{18} \mathrm{O},{ }^{28} \mathrm{Si}^{37} \mathrm{Cl},{ }^{29} \mathrm{Si}^{18} \mathrm{O}^{18} \mathrm{O}$ \\
\hline
\end{tabular}

Purity Standards, Charleston, SC, USA. All standards and sample solutions were prepared using high purity de-ionized water (Milli-Q ${ }^{\mathrm{TM}}$ reagent water system, Millipore Corporation, Bedford, MA, USA). In order to minimize the boron and silicon backgrounds, polypropylene vessels were used throughout this work. The polypropylene vessels used to prepare the sample solutions were soaked overnight in $10 \%$ $\mathrm{HNO}_{3}$, followed by cleaning in an ultrasonic bath and rinsing with deionized water.

\section{Sample Preparation}

The applicability of the method to real samples was demonstrated by the determination of $\mathrm{B}, \mathrm{Al}, \mathrm{P}, \mathrm{Ti}$, $\mathrm{Fe}$, and $\mathrm{Cu}$ in four solar-grade silicon powder samples (100 mesh,

TABLE II

Instrumental ICP-MS Operating Conditions

PerkinElmer ELAN 6100 DRC

Plasma Conditions

RF Power

$1300 \mathrm{~W}$

Plasma argon

flow rate

$15 \mathrm{~L} \mathrm{~min}^{-1}$

Auxiliary argon

flow rate

$1.33 \mathrm{~L} \mathrm{~min}^{-1}$

Carrier argon

flow rate

$0.97 \mathrm{~L} \mathrm{~min}^{-1}$

Data Acquisition

Dwell time

$100 \mathrm{~ms}$

Scan mode

Peak-hopping

Sweeps per reading

Isotopes

monitored

$$
\begin{array}{r}
{ }^{11} \mathrm{~B},{ }^{27} \mathrm{Al},{ }^{31} \mathrm{P},{ }^{47} \mathrm{Ti}, \\
{ }^{48} \mathrm{Ti},{ }^{49} \mathrm{Ti},{ }^{56} \mathrm{Fe},{ }^{57} \mathrm{Fe}, \\
{ }^{63} \mathrm{Cu},{ }^{65} \mathrm{Cu}
\end{array}
$$

Aridus-I Sample Introduction Settings

Sweep gas flow rate $\quad 1.2 \mathrm{~L} \mathrm{~min}^{-1}$ Membrane temperature $\quad 140^{\circ} \mathrm{C}$ $\mathrm{N}_{2}$ gas flow rate $\quad 0 \mathrm{~mL} \mathrm{~min}^{-1}$ Spray chamber temperature $90{ }^{\circ} \mathrm{C}$ Solution flow rate $\quad 60 \mu \mathrm{L} \mathrm{min}{ }^{-1}$ 
99.9-99.99\% purity) obtained from ITRI (Industrial Technology Research Institute, Hsinchu, Taiwan). The procedure was initially applied to the analysis of reference material NIST SRM 1643e Trace Element in Water and the accuracy of the procedure was verified by analyzing the silicon-rich reference material SRM 2711 Montana Soil (National Institute of Standards and Technology, Gaithersburg, MD, USA).

A simple sample dissolution procedure was used in this study as follows: $0.1 \mathrm{~g}$ silicon powder was transferred into a $10-\mathrm{mL}$ polypropylene flask; then $0.1 \mathrm{~mL} 0.5 \%(\mathrm{~m} / \mathrm{v})$ mannitol and $1 \mathrm{~mL}$ concentrated $\mathrm{HNO}_{3}$ were added successively, followed by five $0.2-\mathrm{mL}$ aliquots of concentrated HF (1 mL total). The digest was diluted to the mark with pure water, followed by a 1:10 dilution for ICP-MS analysis. The B, Al, $\mathrm{P}, \mathrm{Ti}, \mathrm{Fe}$, and $\mathrm{Cu}$ concentrations in the sample were quantified by external calibration with $1 \mathrm{ng} \mathrm{mL}^{-1}$ $\mathrm{Rh}$ as the internal standard. For the spike recovery study, $0.1 \mathrm{~g}$ powders of Sample \#4 were spiked with $10 \mu \mathrm{g} \mathrm{g}^{-1}$ of $\mathrm{B}$, Ti and $\mathrm{Cu}, 50 \mu \mathrm{g} \mathrm{g}^{-1}$ of $\mathrm{P}$, and $100 \mu \mathrm{g} \mathrm{g}^{-1}$ of $\mathrm{Al}$ and $\mathrm{Fe}$ (procured from Merck), dried, and then dissolved using the procedure described above.

For studying the effects of various Aridus parameters on the minimization of silicon-induced spectral interferences, a $0.1 \%(\mathrm{~m} / \mathrm{v})$ silicon powder solution of Sample \#4 was used as the model solution. A 1-ng $\mathrm{mL}^{-1}$ Ce solution was used to study the effect of Aridus conditions on the reduction of oxide ion interferences. The SRM 2711 Montana Soil reference sample was dissolved using the method described in a previous paper (14).

\section{RESULTS AND DISCUSSION}

In the preliminary experiments, a microwave-assisted vapor phase dissolution method described in a previous paper was tested to determine $\mathrm{B}, \mathrm{Al}, \mathrm{P}, \mathrm{Ti}, \mathrm{Fe}$, and $\mathrm{Cu}$ in silicon powder (15). These experiments showed that the determined concentrations of $\mathrm{B}$ and $\mathrm{P}$ were lower than the GD-MS values provided by ITRI, even when mannitol was added to the silicon powder before sample dissolution. This could be due to the vaporization loss of $B$ and $\mathrm{P}$ when the sample was heated in a closed system at elevated temperatures. Hence, conventional dissolution was attempted.

Mannitol was used to reduce the vaporization loss during acid dissolution. The effect of the amount of mannitol added to the silicon powder on the recovery of boron was studied. The experiments showed that the recovery was quantitative when $0.1 \mathrm{~g}$ powder was spiked with more than $500 \mu \mathrm{g}$ of mannitol before sample dissolution. In addition to the improvement of boron recovery, the addition of mannitol, $\mathrm{HNO}_{3}$, and $\mathrm{HF}$ could also minimize the memory effect of boron. In this study, a suitable amount of mannitol $(500 \mu \mathrm{g}$ mannitol in $0.1-\mathrm{g}$ silicon powder) was added before sample dissolution.

The determination of phosphorus is difficult since its only isotope $\left({ }^{31} \mathrm{P}^{+}\right)$suffers from severe spectral interference caused by ${ }^{14} \mathrm{~N}^{16} \mathrm{OH}^{+}$ and ${ }^{30} \mathrm{SiH}^{+}$, especially when $\mathrm{HNO}_{3}$ is used for sample dissolution. The DRC ICP-MS with $\mathrm{O}_{2}$ as the reaction gas has been used to minimize the ${ }^{14} \mathrm{~N}^{16} \mathrm{OH}^{+}$interference on phosphorus determination by converting the ${ }^{31} \mathrm{P}^{+}$to ${ }^{31} \mathrm{P}^{16} \mathrm{O}^{+}$in the reaction cell and measuring at $\mathrm{m} / \mathrm{z} 47$ (16). The method was tested for the determination of phosphorus in silicon powder. However, from the experiment it was found that background interference was more serious when the DRC mode was used, due to the interferences caused by the ${ }^{28} \mathrm{Si}^{19} \mathrm{~F}^{+}$and/or ${ }^{30} \mathrm{Si}^{16} \mathrm{OH}^{+}$at $\mathrm{m} / \mathrm{z}$ 47 . Hence, the ICP-MS operated in DRC mode could not be used in

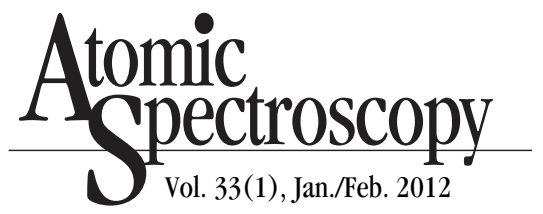

this work. As an alternative, membrane desolvation sample introduction was attempted.

\section{Selection of Aridus Conditions}

As shown in Table I, the determination of $\mathrm{Al}, \mathrm{P}, \mathrm{Ti}, \mathrm{Fe}$, and $\mathrm{Cu}$ in solutions with a high silicon content by quadrupole ICP-MS suffers from high background problems. In order to evaluate the significance of these interferences, experiments were performed to check the interferences caused by silicon-induced ions. Solutions containing $10 \mathrm{ng} \mathrm{mL}^{-1}$ $\mathrm{Al}, \mathrm{Ti}$ and $\mathrm{Fe}, 100 \mu \mathrm{g} \mathrm{mL}^{-1} \mathrm{Si}$ in $1 \%$ (v/v) $\mathrm{HF}$ and $1 \%(\mathrm{v} / \mathrm{v}) \mathrm{HNO}_{3}$ and $1 \%$ (v/v) $\mathrm{HNO}_{3}$ (to be treated as blank) were prepared. The solutions were introduced into the ICP-MS by conventional cross-flow pneumatic nebulization with a Scott-type spray chamber. The ion signals at the masses of interest were determined, and the results are shown in Figure 1. As shown, a solution containing $100 \mu \mathrm{g} \mathrm{mL}^{-1}$ Si in $1 \%(\mathrm{v} / \mathrm{v}) \mathrm{HF}$ and $1 \%(\mathrm{v} / \mathrm{v}) \mathrm{HNO}_{3}$ produced a background signal equivalent to 4.5 times of the signal of $10 \mathrm{ng} \mathrm{mL}^{-1} \mathrm{Ti}$ at $\mathrm{m} / \mathrm{z} 47$ and $26 \%$ of the signal of $10 \mathrm{ng} \mathrm{mL}^{-1} \mathrm{Ti}$ at $\mathrm{m} / \mathrm{z} 49$. To minimize the interference, after evaluation, a sample introduction device with membrane disolvation (Aridus-I) was selected for this study. Various parameters of the Aridus, including nebulizer gas flow rate, sweep gas flow rate, membrane temperature, and $\mathrm{N}_{2}$ gas flow rate, were studied to achieve maximum ion signals and minimum background interferences. Both of the ion signals of the elements studied and the ratios of ${ }^{47} \mathrm{Ti} /{ }^{49} \mathrm{Ti}$ and $\mathrm{CeO} / \mathrm{Ce}$ were monitored. The ${ }^{47} \mathrm{Ti} /{ }^{49} \mathrm{Ti}$ ratio will be larger than 1.33 (the natural isotopic abundance ratio of ${ }^{47} \mathrm{Ti} /{ }^{49} \mathrm{Ti}$ ) when the determination of ${ }^{47} \mathrm{Ti}^{+}$and ${ }^{49} \mathrm{Ti}^{+}$ is interfered by ${ }^{28} \mathrm{Si}^{19} \mathrm{~F}^{+}$and ${ }^{30} \mathrm{Si}^{19} \mathrm{~F}^{+}$, respectively. $\mathrm{A}^{47} \mathrm{Ti} /{ }^{49} \mathrm{Ti}$ ratio close to 1.33 and a small value of $\mathrm{CeO} / \mathrm{Ce}$ indicates the minimization of spectral interferences. In this study, $0.1 \%(\mathrm{~m} / \mathrm{v})$ solution of silicon pow- 
der \#4 and $1 \mathrm{ng} \mathrm{mL}^{-1}$ Ce solution were used as the model solutions.

The effects of nebulizer gas flow rate on the $\mathrm{Ti}$ signal and ${ }^{47} \mathrm{Ti} /{ }^{49} \mathrm{Ti}$ ratio are shown in Figure 2. As shown, the Ti signal increased with an increase of nebulizer gas flow rate due to the increase of nebulization efficiency. Meanwhile, the ${ }^{47} \mathrm{Ti} /{ }^{49} \mathrm{Ti}$ ratio increased with the nebulizer gas flow rate when the gas flow rate was less than $0.89 \mathrm{~L} \mathrm{~min}^{-1}$. The effect of nebulizer gas flow rate on oxide formation was also studied. As shown in Figure 3, the Ce ion signal increased with an increase in gas flow rate, while the $\mathrm{CeO} / \mathrm{Ce}$ ratio decreased slightly with the nebulization gas flow rate. A nebulization gas flow rate of $0.97 \mathrm{~L} \mathrm{~min}^{-1}$ was selected for this study.
A sweep gas is needed to remove the $\mathrm{SiF}_{4}$ and the solvent vapor after they penetrate the membrane. The effect of the sweep gas flow rate on the ion signals and the background interferences are shown in Figure 4 . It can be seen that the $\mathrm{Ti}^{+}$signal increased with an increase of sweep gas flow when the flow rate was less than $1.2 \mathrm{~L} \mathrm{~min}^{-1}$.

The increase of the ion signal could be due to the removal of the major matrix component which minimized the ion suppression effect. When the sweep gas flow rate was larger than $1.2 \mathrm{~L} \mathrm{~min}^{-1}$, the $\mathrm{Ti}^{+}$signal decreased and the ${ }^{47} \mathrm{Ti} /{ }^{49} \mathrm{Ti}$ ratio increased. The high sweep gas flow rate might prohibit the penetration of $\mathrm{SiF}_{4}$ vapor through the membrane and cause non-spectral and spectral interferences. As shown in Figure 5, a similar behavior was detected for the $\mathrm{Ce}$ ion signal and $\mathrm{CeO} / \mathrm{Ce}$ ratio. As can be seen, the Ce ion signal decreased and the $\mathrm{CeO} / \mathrm{Ce}$ ratio increased when the sweep gas flow rate was larger than $1.2 \mathrm{~mL} \mathrm{~min}^{-1}$. Hence, $1.2 \mathrm{~mL} \mathrm{~min}^{-1}$ was selected for the following experiments.

The effects of nitrogen gas flow rate on the $\mathrm{Ti}$ ion signal and ${ }^{47} \mathrm{Ti} /{ }^{49} \mathrm{Ti}$ ratio are shown in Figure 6. As shown, the Ti signal decreased significantly with an increase in the $\mathrm{N}_{2}$ gas flow rate. In contrast, the ${ }^{47} \mathrm{Ti} /{ }^{49} \mathrm{Ti}$ ratio increased slightly with the $\mathrm{N}_{2}$ gas flow rate. Although not shown, the $\mathrm{CeO} / \mathrm{Ce}$ ratio also increased slightly with the $\mathrm{N}_{2}$ gas flow rate. In this study, no $\mathrm{N}_{2}$ gas was added (i.e., $\mathrm{N}_{2}$ flow $=0$ ).

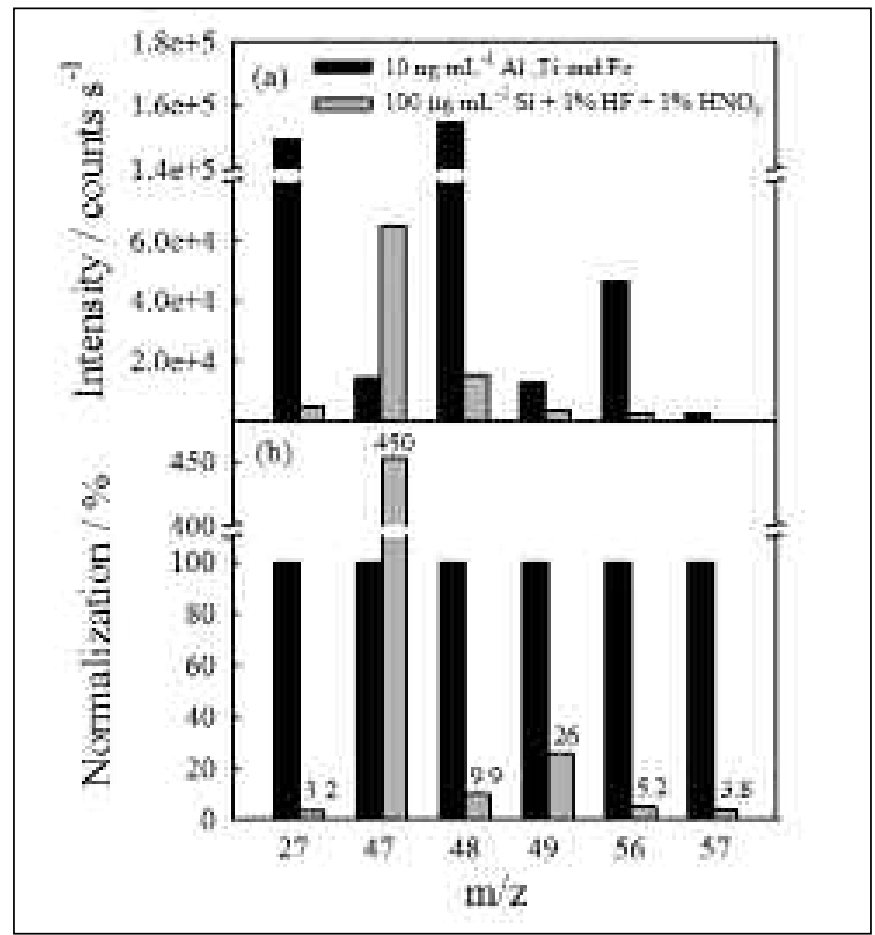

Fig. 1. Ion signals of $10 \mathrm{ng} \mathrm{mL}^{-1}$ of $\mathrm{Al}$, Ti. and Fe and background signals of $100 \mu \mathrm{gL}^{-1}$ Si in $1 \% v / v$ HF and $1 \% v / v$ $\mathrm{HNO}_{3}$ solution; (a) ion signal and (b) relative signal.

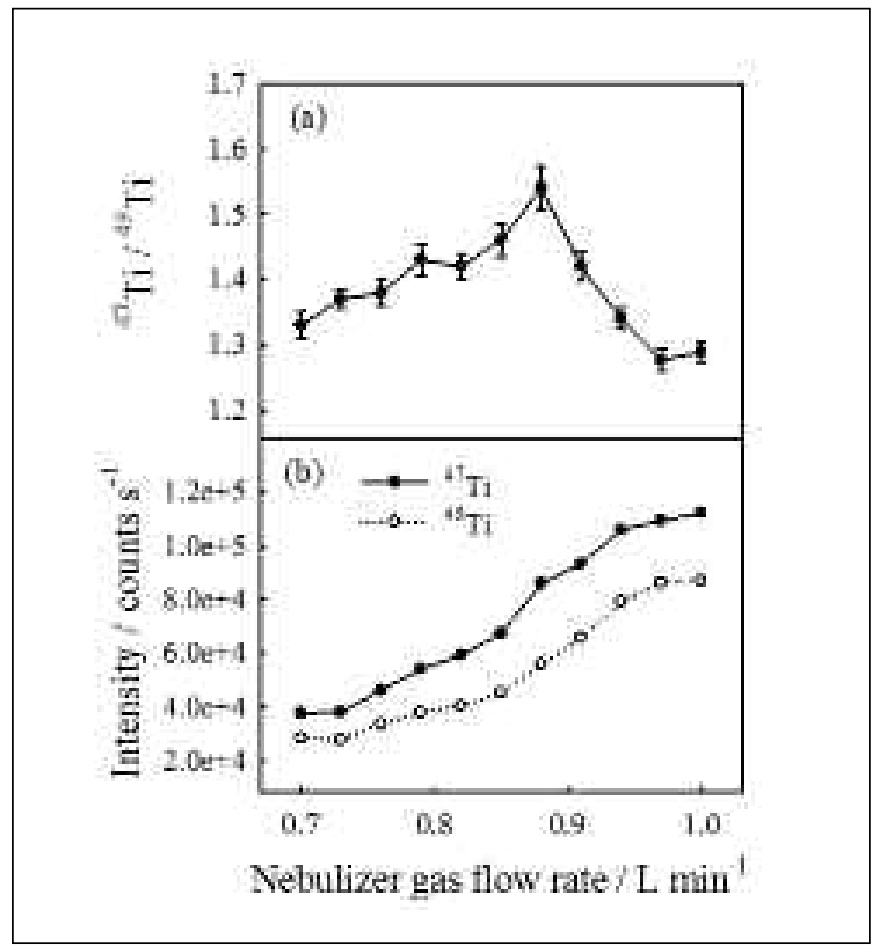

Fig. 2. Effects of nebulizer gas flow rate on Ti ion signal and ${ }^{47} \mathrm{Ti} /{ }^{49} \mathrm{Ti}$ ratio. Membrane temperature $=160^{\circ} \mathrm{C}$; Sweep gas flow rate $=1.2 \mathrm{~L} \mathrm{~min}^{-1} ; \mathrm{N}_{2}$ gas flow rate $=0 \mathrm{~mL} \mathrm{\textrm {min } ^ { - 1 } .}$ 


\section{Atomic Apectroscopy \\ $\bigcup$ Vol. 33(1), Jan./Feb. 2012}

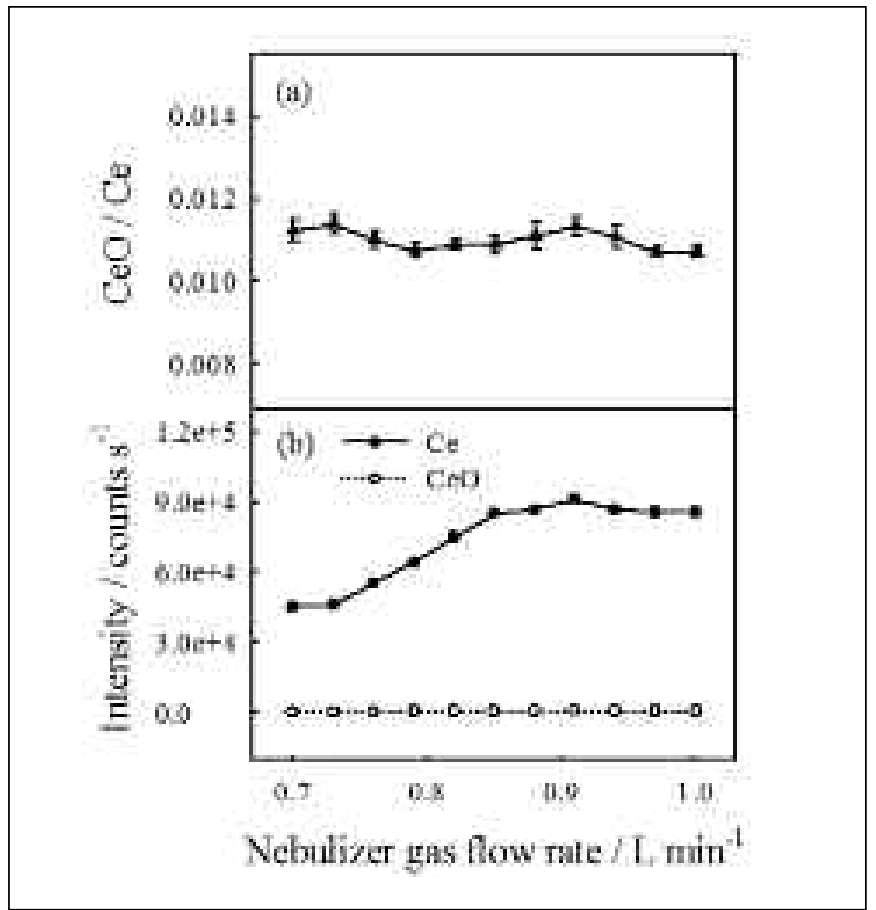

Fig. 3. Effects of nebulizer gas flow rate on Ce ion signal and $\mathrm{CeO} / \mathrm{Ce}$ ratio. Membrane temperature $=160^{\circ} \mathrm{C}$; Sweep gas flow

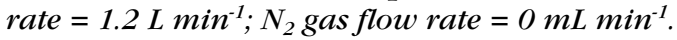

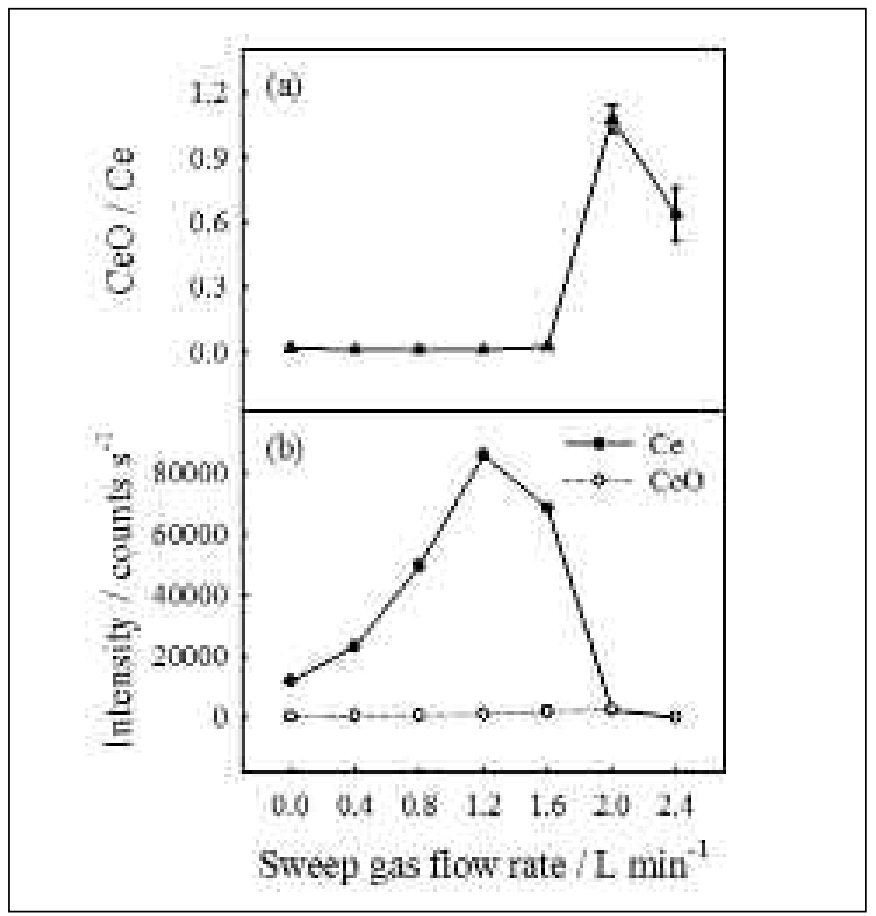

Fig. 5. Effect of the sweep gas flow rate on Ce ion signal and $\mathrm{CeO} / \mathrm{Ce}$ ratio. Nebulization gas flow rate $=0.97 \mathrm{~L} \mathrm{~min}^{-1} ; \mathrm{Mem}$ brane temperature $=160^{\circ} \mathrm{C} ; \mathrm{N}_{2}$ gas flow rate $=0 \mathrm{~mL} \mathrm{~min}$.

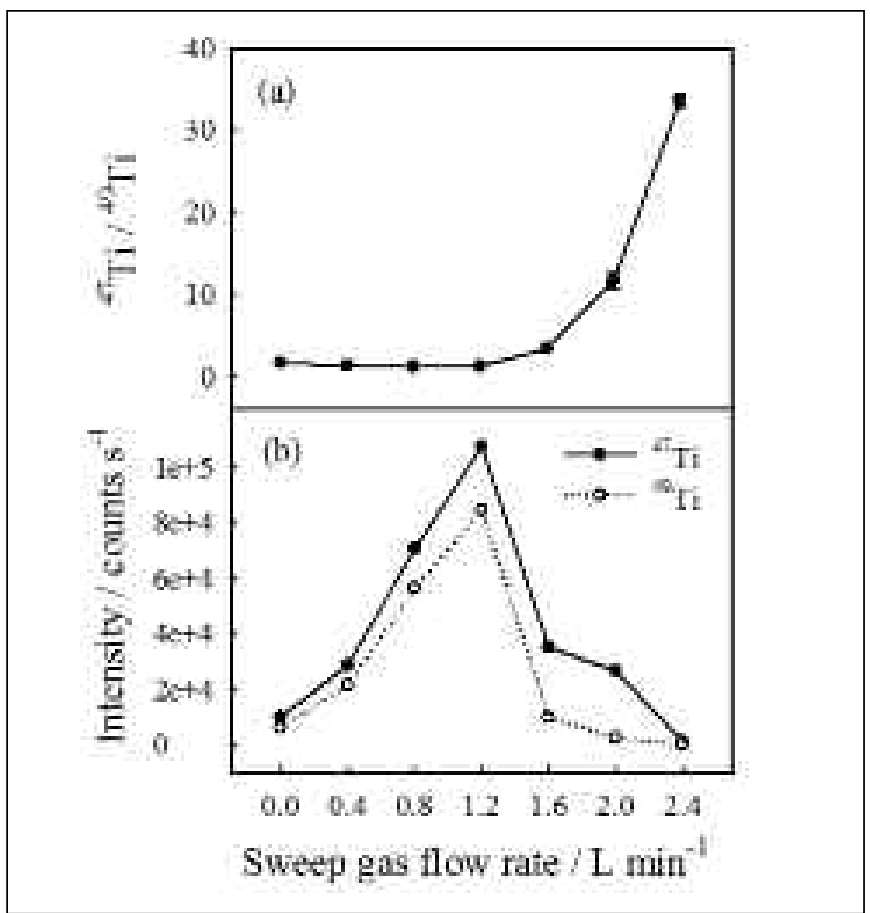

Fig. 4. Effect of the sweep gas flow rate on Ti ion signal and ${ }^{47} \mathrm{Ti}{ }^{49} \mathrm{Ti}$ ratio. Nebulization gas flow rate $=0.97 \mathrm{~L} \mathrm{~min}^{-1}$; Membrane temperature $=160^{\circ} \mathrm{C} ; \mathrm{N}_{2}$ gas flow rate $=0 \mathrm{~mL} \mathrm{~min}$.

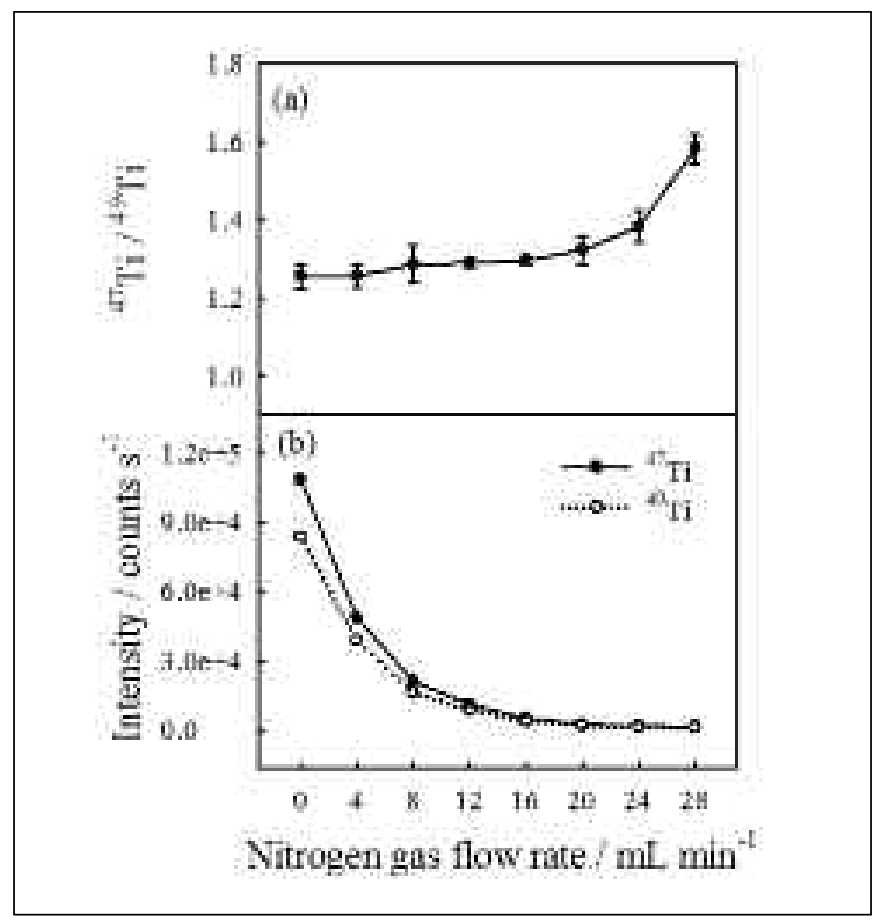

Fig. 6. Effects of nitrogen gas flow rate on Ti ion signal and ${ }^{47} \mathrm{Ti} /{ }^{49} \mathrm{Ti}$ ratio. Nebulization gas flow rate $=0.97 \mathrm{~L} \mathrm{~min}^{-1} ; \mathrm{Mem}-$ brane temperature $=160^{\circ} \mathrm{C}$; Sweep gas flow rate $=1.2 \mathrm{~L} \mathrm{~min}^{-1}$. 
The effect of membrane temperature on the Ti ion signal and the ${ }^{47} \mathrm{Ti} /{ }^{49} \mathrm{Ti}$ ratio is shown in Figure 7. As shown, the increase of membrane temperature did not affect the ${ }^{47} \mathrm{Ti} /{ }^{49} \mathrm{Ti}$ ratio; however, the signal of $\mathrm{Ti}$ increased slightly with the membrane temperature, which could be due to the more effective removal of the Si matrix. It was also found that the membrane temperature did not affect the $\mathrm{CeO} / \mathrm{Ce}$ ratio when the temperature was higher than $110^{\circ} \mathrm{C}$. Furthermore, the boron signal decreased slightly when the membrane temperature was higher than $130{ }^{\circ} \mathrm{C}$. The decrease of boron ion signal could be due to the vaporization of boron. After evaluation, $140^{\circ} \mathrm{C}$ was selected. A summary of the optimized operating conditions of the membrane desolvation ICP-MS is given in Table II (see page 2).

Figure 8 shows the reduction of spectral interferences in the determination of $\mathrm{Al}, \mathrm{Ti}$, and $\mathrm{Fe}$ when the
Aridus was employed as a sample introduction device. As shown, the background at $\mathrm{m} / \mathrm{z} 47$ reduced significantly when the Aridus was used as the sample introduction device. The remaining background signals detected at various isotopes could be due to the trace contamination of the analytes in the reagents used for the preparation of the simulated matrix solution. Furthermore, from the experiment it was found that the background ion signal at $\mathrm{m} / \mathrm{z} 31$ and 57 was reduced from 13,200 and $8490 \mathrm{c} \mathrm{s}^{-1}$ to 1540 and $695 \mathrm{c} \mathrm{s}^{-1}$, respectively, when a blank solution containing $5 \mu \mathrm{g} \mathrm{mL} \mathrm{m}^{-1}$ mannitol in $1 \% \mathrm{HNO}_{3}$ and $1 \% \mathrm{HF}$ was introduced. These experiments demonstrated the effectiveness of the Aridus sample introduction system for the minimization of spectral interferences in ICP-MS analysis. Under the optimum conditions, calibration curves (six points) in the range of $5-300 \mathrm{ng} \mathrm{mL}^{-1}$ for $\mathrm{P}$ and 1-50 ng $\mathrm{mL}^{-1}$ for $\mathrm{B}, \mathrm{Al}, \mathrm{Ti}, \mathrm{Fe}$, and
Cu were linear with a coefficient of determination $\left(r^{2}\right)$ better than 0.9991 . The detection limit estimated from the calibration curve was better than $0.02,0.007$, $0.1,0.004,0.1$, and $0.002 \mathrm{ng} \mathrm{mL}^{-1}$ for $\mathrm{B}, \mathrm{Al}, \mathrm{P}, \mathrm{Ti}, \mathrm{Fe}$, and $\mathrm{Cu}$, respectively. The detection limits obtained in this work are low enough to determine various trace elements in solar-grade silicon.

Determination of $\mathrm{B}, \mathrm{Al}, \mathrm{P}, \mathrm{Ti}, \mathrm{Fe}$, and $\mathrm{Cu}$ in Reference Materials and Silicon Powder

In order to prove that the proposed method is suitable for practical analysis, the concentrations of $\mathrm{B}, \mathrm{Al}, \mathrm{P}, \mathrm{Ti}, \mathrm{Fe}$, and $\mathrm{Cu}$ were determined in NIST SRM 1643e Trace Element in Water and NIST SRM 2711 Montana Soil reference samples, and four silicon powder samples obtained from ITRI. The concentrations of $\mathrm{B}, \mathrm{Al}, \mathrm{P}, \mathrm{Ti}, \mathrm{Fe}$, and $\mathrm{Cu}$ present in these samples were quantified by the external

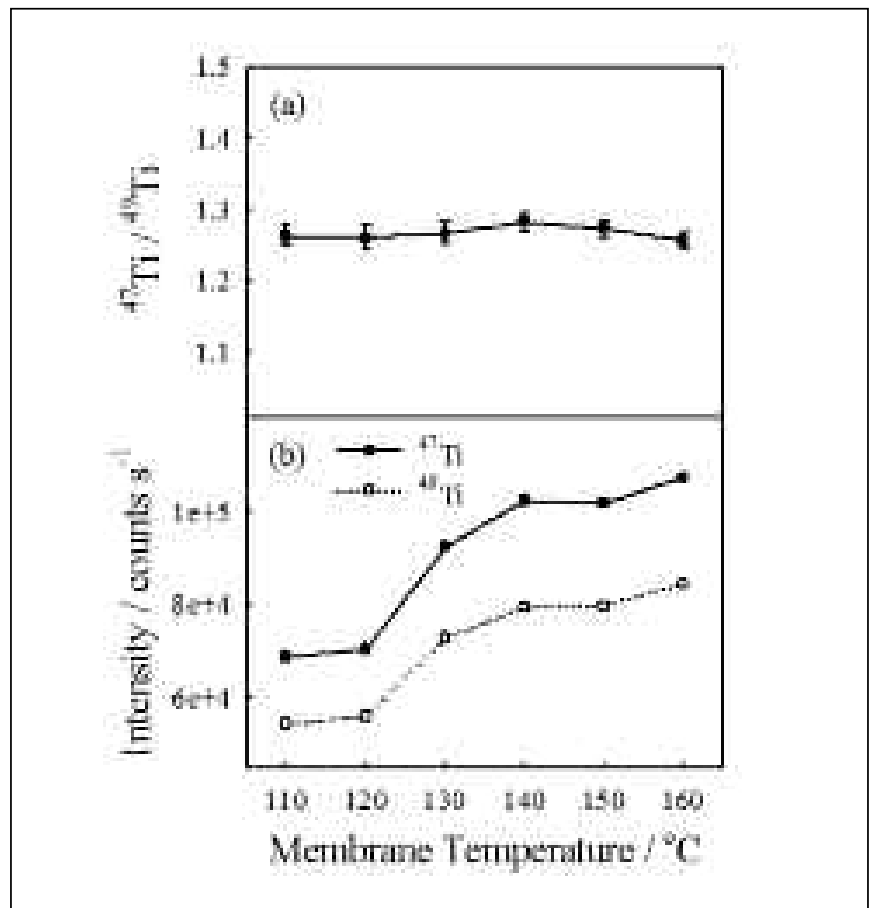

Fig. 7. Effect of membrane temperature on Ti ion signal and the ${ }^{47} \mathrm{Ti} /{ }^{49} \mathrm{Ti}$ ratio. Nebulization gas flow rate $=0.97 \mathrm{~L} \mathrm{~min}{ }^{-1}$;

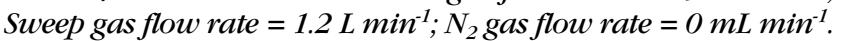

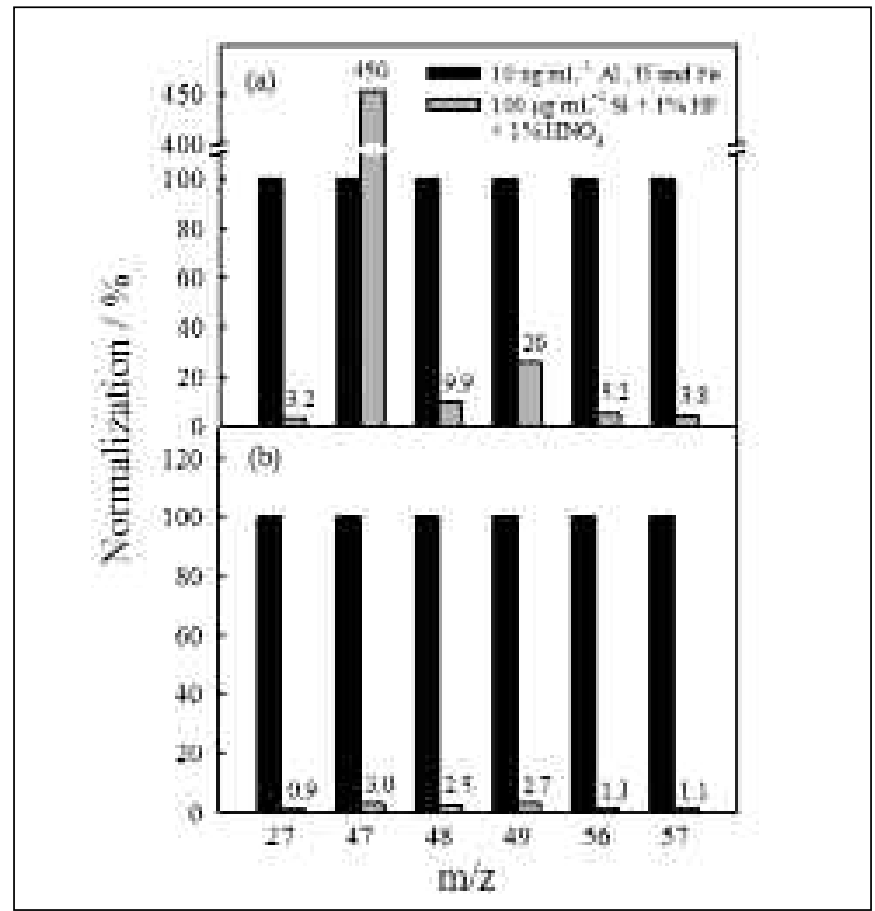

Fig. 8. Ion signals of $10 \mathrm{ng} \mathrm{mL}^{-1}$ of Al, Ti and Fe and background signals of $100 \mu \mathrm{g} \mathrm{mL} \mathrm{L}^{-1}$ Si in $1 \% \mathrm{v} / \mathrm{v} \mathrm{HF}$ and $1 \% v / v$ HNO3 solution when (a) conventional cross-flow nebulizer and (b) Aridus was used as the sample introduction device, respectively. 
calibration method with $1 \mathrm{ng} \mathrm{mL} \mathrm{mL}^{-1}$ $\mathrm{Rh}$ as the internal standard. The analysis results of the reference samples are listed in Table III. Agreement of the obtained results with the certified values of the standard reference materials was good.

The developed method was applied to the determination of $\mathrm{B}$, $\mathrm{Al}, \mathrm{P}, \mathrm{Ti}, \mathrm{Fe}$, and $\mathrm{Cu}$ in four solargrade silicon powder samples. The results are listed in Table IV. As shown, the $\mathrm{Al}, \mathrm{Ti}$, and $\mathrm{Fe}$ results of the conventional pneumatic nebulization method were high, most likely due to the interferences caused by the silicon-induced ions. The membrane desolvation ICP-MS results of $\mathrm{B}, \mathrm{P}, \mathrm{Fe}$, and $\mathrm{Cu}$ were in good agreement with the GD-MS reference values, although the $\mathrm{Al}$ and Ti results were higher than the GD-MS values, possibly due to inhomogeneity or RSF values. However, the DRC will alleviate the interferences associated with the determination of $\mathrm{Al}, \mathrm{Fe}$, and $\mathrm{Cu}$. However, the aim of the present work is the development of a simpler procedure and hence DRC was not used. (As mentioned in the text, the GDMS values are given by ITRI). Furthermore, the membrane desolvating ICP-MS results of $\mathrm{B}, \mathrm{Al}, \mathrm{P}, \mathrm{Fe}$, and $\mathrm{Cu}$ determination were in good agreement with those obtained by USS-ETV-ICP-MS (17) in accordance with the Student's $t$-test for a confidence level of $95 \%$. The spiked recovery was determined using the procedure described in the experi- mental section. The recovery was in the $94-107 \%$ range for the elements studied. Hence, the proposed membrane desolvation ICP-MS method is suitable for the determination of $\mathrm{B}, \mathrm{Al}, \mathrm{P}, \mathrm{Ti}, \mathrm{Fe}$, and $\mathrm{Cu}$ in silicon powder.

\section{CONCLUSION}

The use of pneumatic nebulization membrane desolvation inductively coupled plasma mass spectrometry (ICP-MS) provides a simple, rapid, and accurate technique to determine $\mathrm{B}, \mathrm{Al}, \mathrm{P}, \mathrm{Ti}, \mathrm{Fe}$, and $\mathrm{Cu}$ routinely in solar-grade silicon samples. The effectiveness of the membrane desolvation system for the alleviation of spectral interferences was demonstrated. As a result of interference-free measurements, detection limits of better than $0.02,0.007,0.1,0.004,0.1$, and $0.002 \mathrm{ng} \mathrm{mL}^{-1}$ for $\mathrm{B}, \mathrm{Al}, \mathrm{P}, \mathrm{Ti}$, $\mathrm{Fe}$ and $\mathrm{Cu}$, respectively, were achieved. An easy and simple sample dissolution method was developed. The addition of mannitol for the minimization of boron vaporization loss has also been demonstrated.

\section{ACKNOWLEDGMENT}

This research was supported by a grant from the Industrial Technology Research Institute (ITRI) of the Republic of China

Received September 21, 2011

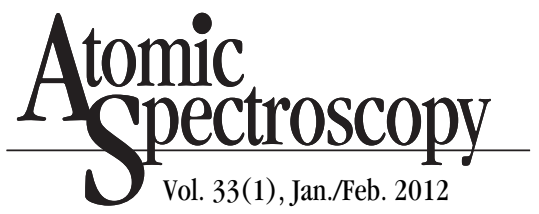

\section{REFERENCES}

1. N. Streckfu, L. Frey, G. Zielonka, F. Kroninger, C. Ryzlewicz and $\mathrm{H}$. Ryssel, Fresenius' J. Anal. Chem. 343, 765 (1992).

2. W. Berneike, Spectrochim. Acta, Part B 48, 269 (1993).

3. M. Yamagami, A. Ikeshita, Y. Onizuka, S. Kojima and T. Yamada, Spectrochim. Acta, Part B 58, 2079 (2003).

4. P. K. Chu, Mater. Chem. Phys. 38, 203 (1994)

5. D. Romero, J. M. F. Romero and J. J. Romero, J. Anal. At. Spectrom. 14, 199 (1999).

6. M. Milan, P. Lucena, L. M. Cabalin and J. J. Laserna, Appl. Spectrosc. 52, 444 (1998).

7. T. Nelis and J. Pallosi, Appl. Spectrosc. Rev. 41, 227 (2006).

8. D.H. Sun, R.L. Ma, C. W. McLeod, X. -R. Wang and A. G. Cox, J. Anal. At. Spectrom. 15, 257 (2000).

9. T. Ishikawa and E. Nakamura, Anal. Chem. 62, 2612 (1990).

10. I.-L. Chang, I.H. Hsu, M.H. Yang and Y. -C. Sun, J. Chromatography A, 1217, 1362 (2010).

11. J. Takahashi, American Laboratory, 41, 28 (2009).

12. J.M.Chen, W. You, J.B. Du, H.H. Pan, ECS Transactions, 27, 1141 (2010).

13. C. Fragniere, M. Haldimann, A. Eastgate and U. Krahenbuhl, J. Anal. At. Spectrom. 20, 626 (2005).

TABLE III

Determination of B, Al, P, Ti, Fe and Cu in Standard Reference Materials by Membrane Desolvation ICP-MS ${ }^{a}$ $(\mathbf{n}=3)$

\begin{tabular}{|c|c|c|c|c|c|c|c|}
\hline \multicolumn{2}{|l|}{ Sample } & B & $\mathrm{Al}$ & $\mathrm{P}$ & $\mathrm{Ti}$ & $\mathrm{Fe}$ & $\mathrm{Cu}$ \\
\hline \multicolumn{8}{|c|}{ NIST SRM 2711} \\
\hline \multirow[t]{2}{*}{ Montana soil } & Measured value & - & $2.64 \pm 0.10^{\mathrm{c}}$ & $0.087 \pm 0.002^{\mathrm{c}}$ & $0.317 \pm 0.018^{c}$ & $2.78 \pm 0.06^{\mathrm{c}}$ & $114 \pm 1^{\mathrm{d}}$ \\
\hline & Certified value & -- & $2.00 \sim 3.10^{\mathrm{b}, \mathrm{c}}$ & $0.086 \pm 0.007^{\mathrm{c}}$ & $0.306 \pm 0.023^{c}$ & $2.89 \pm 0.06^{\mathrm{c}}$ & $114 \pm 2^{\mathrm{d}}$ \\
\hline \multicolumn{8}{|c|}{ NIST SRM $1643 \mathrm{e}$} \\
\hline \multirow[t]{2}{*}{ Fresh water } & Measured value & $155.7 \pm 0.8^{\mathrm{e}}$ & $147.3 \pm 1.5^{\mathrm{e}}$ & - & - & $102.5 \pm 3.4^{\mathrm{e}}$ & $22.71 \pm 0.13^{\mathrm{e}}$ \\
\hline & Certified value & $157.9 \pm 3.9^{\mathrm{e}}$ & $141.8 \pm 8.6^{\mathrm{e}}$ & - & _- & $98.1 \pm 1.4^{\mathrm{e}}$ & $22.76 \pm 0.31^{\mathrm{e}}$ \\
\hline
\end{tabular}

\footnotetext{
${ }^{a}$ Values are means of three measurements \pm standard deviation

${ }^{\mathrm{b}}$ Leach data range; ${ }^{\mathrm{c}}$ Values are in \%; ${ }^{\mathrm{d}}$ Values are in $\mu \mathrm{g} \mathrm{g}^{-1}$; ${ }^{\mathrm{e}}$ Values are in $\mathrm{ng} \mathrm{mL}^{-1}$.
} 
TABLE IV

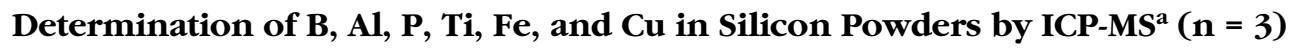

\begin{tabular}{|c|c|c|c|c|c|c|c|c|}
\hline Sample & Method & B & $\mathrm{Al}$ & $\mathrm{P}$ & ${ }^{47} \mathrm{Ti}$ & ${ }^{48} \mathrm{Ti}$ & $\mathrm{Fe}$ & $\mathrm{Cu}$ \\
\hline \multirow[t]{4}{*}{ Sample \#1 } & Cross-flow & & & & & & & \\
\hline & Nebulizer $^{\mathrm{b}}$ & $13.3 \pm 0.4$ & $81.3 \pm 7.1$ & $52.6 \pm 3.4$ & $276 \pm 11$ & $16.7 \pm 0.6$ & $87.7 \pm 4.8$ & $197 \pm 5$ \\
\hline & ARIDUS $^{\mathrm{c}}$ & $14.0 \pm 0.7$ & $76.9 \pm 4.3$ & $43.6 \pm 1.7$ & $14.4 \pm 0.2$ & $13.3 \pm 0.3$ & $82.2 \pm 4.8$ & $203 \pm 2$ \\
\hline & $\mathrm{GD}^{-M^{\mathrm{d}}}$ & n.a. ${ }^{e}$ & 51 & n.a. & 11 & 74 & 258 & \\
\hline \multirow[t]{4}{*}{ Sample \#2 } & Cross-flow & & & & & & & \\
\hline & Nebulizer & $12.4 \pm 0.3$ & $149 \pm 7$ & $76.2 \pm 2.7$ & $258 \pm 14$ & $28.6 \pm 1.2$ & $112 \pm 4$ & $17.0 \pm 0.6$ \\
\hline & ARIDUS & $12.7 \pm 0.6$ & $136 \pm 4$ & $66.3 \pm 1.4$ & $28.0 \pm 0.9$ & $26.6 \pm 0.6$ & $101 \pm 4$ & $16.7 \pm 0.2$ \\
\hline & GD-MS & 11 & 110 & 66 & 22 & 94 & 22 & \\
\hline \multirow[t]{4}{*}{ Sample $\# 3$} & Cross-flow & & & & & & & \\
\hline & Nebulizer & $155 \pm 5$ & $154 \pm 11$ & $73.9 \pm 2.6$ & $252 \pm 9$ & $27.5 \pm 0.9$ & $171 \pm 5$ & $9.8 \pm 0.4$ \\
\hline & ARIDUS & $151 \pm 7$ & $146 \pm 8$ & $57.6 \pm 2.6$ & $27.8 \pm 0.3$ & $25.1 \pm 0.6$ & $163 \pm 2$ & $9.8 \pm 0.2$ \\
\hline & GD-MS & 150 & 120 & 58 & 19 & 160 & 8.9 & \\
\hline \multirow[t]{4}{*}{ Sample \#4 } & & Cross-flow & & & & & & \\
\hline & Nebulizer & $13.5 \pm 0.3$ & $155 \pm 8$ & $79.2 \pm 3.8$ & $267 \pm 10$ & $32.6 \pm 0.6$ & $164 \pm 3$ & $7.2 \pm 0.1$ \\
\hline & ARIDUS & $14.2 \pm 0.8$ & $147 \pm 4$ & $57.7 \pm 1.1$ & $31.8 \pm 0.7$ & $29.3 \pm 0.2$ & $156 \pm 6$ & $7.4 \pm 0.1$ \\
\hline & GD-MS & 14 & 110 & 62 & 24 & 160 & 8.8 & \\
\hline
\end{tabular}

${ }^{\mathrm{a}}$ Values are means of three measurements \pm standard deviation; all values are in $\mu \mathrm{g} \mathrm{\textrm {g } ^ { - 1 }}$.

${ }^{\text {b }}$ Sample solution contained $0.1 \% \mathrm{~m} / \mathrm{v}$ silicon powder, $5 \mu \mathrm{g} \mathrm{mL}^{-1}$ mannitol in $1 \% \mathrm{HNO}_{3}$ and $1 \% \mathrm{HF}$. Solutions were introduced with conventional cross-flow nebulizer.

c Sample solution contained $0.1 \% \mathrm{~m} / \mathrm{v}$ silicon powder, $5 \mu \mathrm{g} \mathrm{mL} \mathrm{L}^{-1}$ mannitol in $1 \% \mathrm{HNO}_{3}$ and $1 \% \mathrm{HF}$.

Solutions were introduced with Aridus-I system.

${ }^{\mathrm{d}}$ GD-MS reference values were provided by ITRI.

e Not available.

14. N. N. Meeravali and S. -J. Jiang, J. Anal. At. Spectrom. 23, 1365 (2008).

15. R.-L. Ueng, S.-J. Jiang, C.-C. Wan and A. C. Sahayam, Anal. Chim. Acta, 536, 295 (2005).

16. C.-H. Yang and S.-J. Jiang, Spectrochim. Acta, Part B 59, 1389 (2004).

17. P.-K. Hsiao, S.-J. Jiang and A. C. Sahayam, J. Anal. At. Spectrom. 26, 586 (2011). 